\title{
Effects of Climate Change Adaptation Measures on Groundnut Production Efficiency in Benue State, Nigeria
}

\author{
Ezihe, J.A.C.; Ivom, G.A. and Aye, G.C.
}

Department of Agricultural Economics, Federal University of Agriculture, Makurdi.

Corresponding Author: ivomga87@gmail.com

\begin{abstract}
This study assessed the effects of climate change adaptation strategies on groundnut production efficiency. The population for the study consists of all groundnut farmers in Benue State. Primary data were collected from 205 sampled groundnut farmers using multistage sampling technique. The data were analysed using descriptive and inferential statistics. The result showed that the average age of the respondents was 36 years. Groundnut farming in the study area was dominated by the male. Majority of the farmers were married with an average of 6 persons per household. The study reveals that $82.9 \%$ and $74.1 \%$ of the respondents do not have access to extension services and credit respectively. The result of the stochastic frontier analysis revealed that the average technical efficiency of groundnut production was 0.90 . The respondents were aware of climate change and adopted measures to cope with the changing climate. The inefficiency model showed that adoption of improved/multiple varieties and planting of trees to cope with climate change significantly increased inefficiency at 5\% level of significance; off-farm employment significantly increased inefficiency at $10 \%$ level of significance; adjustment of/multiple planting dates and alternative tillage practices significantly decreased inefficiency at $1 \%$ level of significance. Inadequate access to credit and extension services hindered appropriate use of adaptation measures, hence, there is need to emphasize adequate education with the help of extension agents to facilitate the farmers' adaptation to climate change and there is need also for government to support creditfacilities to help improve farmers' capacity to adapt to climate change.

Keywords-climate change, adaptation measures, technical efficiency, groundnut production.
\end{abstract}

\section{INTRODUCTION}

Agriculture is highly exposed to climate change, as farming activities directly depend on climate condition. The pattern of the effects of climate change are dependent on latitude, altitude, type of crop grown and livestock reared (Khanal, 2009). Mark et al., (2008) highlighted some direct impacts of climate change on agricultural system as; seasonal changes in rainfall and temperature, which could impact agro-climatic conditions, altering growing seasons, planting and harvesting calendars, water availability, pest and disease populations; alteration in evapotranspiration, photosynthesis and biomass production; and alteration in land suitability for agricultural production.Food production including access to food is projected to be highly compromised by climate variability and change (Intergovernmental panel on climate change, IPCC, 2007).

High variation in environ mental factors such as temperature, rainfall and others affect crop growth negatively and certain crops get positively affected due to changes in environmental factors. Rise in temperature for example helps to grow crops in high altitude areas and towards the poles for example. In such areas, an increase in temperature extends the length of potential growing season, allowing earlier planting, early harvesting and opening the possibility of completing two crops cycles in the same season (Khanal, 2009). High growing season temperature can significantly impact agricultural productivity, farm incomes and food security (Battisti \& Naylor, 2009).

Adaptation is one of the policy options for reducing the negative impact of climate change (Kurukulasuriya \& Mendelsohn, 2006). Adaptation refers to all adjustments in behaviour or economic structure that reduce vulnerability of the society to changes in the climate system including its current variability and extreme events as well as long-term climate change (Smit et al., 2000). Adaptation to climate change necessitates that farmers first notice that the climate has changed and then identify useful adaptation and implement them (Maddison, 2006). Common adaptation methods in agriculture include the use of new crop varieties and 
livestock breeds that are more suited to drier conditions, irrigation, crop diversification, mixed crop and livestock farming system, change of planting dates, diversification from farm to non-farming activities, increase use of soil water conservation, changed use of capital, labour and trees planted for shade and shelter (Nhemachena\& Hassan, 2007; Mendelsohn, 2006).Adaptation capacity is the potential or ability of a system, region or community to adapt to the effects or impact of climate change (Smit\&Pilifosova, 2001). Adaptation strategies determine the productivity of the ecosystem.

Groundnut (Arachis hypogaea L) is also known as peanuts, pinders, manila nuts, earthnuts or gobbers (Beghin, et al., 2003). It is a member of the genus Arachis in the family leguminosae (Fabacaea) which has replaced the traditional bambara groundnut (Vigna subterranean) in some areas (Ashley, 1993). Groundnut is the $13^{\text {th }}$ most important food crop and $4^{\text {th }}$ in oil seed crop of the world. Groundnut is grown in different rainfall and temperature regimes on a variety of soils. Depending upon the location on the globe, climate change may benefit or adversely affect the productivity of this crop.

Groundnut seeds (Kernels) contains 40-50\% fat, $20-50 \%$ protein and 10-20\% carbohydrates (Food and Agriculture Organization, FAO, 2006). Groundnut kernels are consumed directly as raw, roasted or boiled kernels or oil extracted from the kernels is used as culinary oil. It is used as animal feed (oil pressing, seeds, green oil cakes and fertilizer). Groundnut seeds are nutritional source of vitamin E, niacin, falacin, calcium, phosphorus, magnesiu $\mathrm{m}$, zinc, iron, riboflav in, thiamine and potassium (FAO, 2006). The uses of groundnut plant makes it an excellent cash crop for domestic markets as well as for foreign trade in several developing and developed countries (FAO, 2006).

The results of studies carried out in the past in specific locations to determine the effects of climate change and climate change adaptation strategies directly depend on the extent of climate variation, crop and livestock response and specific adaptation strategies. Hence the need for this study which aims at revealing the farmers' perception of climate change; adaptation strategies adopted by the farmers; and estimating the technical efficiency of groundnut production and the effects of the adopted strategies on technical efficiency of groundnut production.

\section{METHODOLOGY}

The Study Area.

The study was carried out in Benue State, Nigeria. Benue State is located in the North-Central region of Nigeria between Latitudes $6^{0} 25^{\prime}$ and $8^{0} 8^{\prime} \mathrm{N}$ and Longitude $7^{0} 47^{\prime}$ and $10^{\circ} 0^{\prime} \mathrm{E}$. The state has a population of 4,252,641 people (National Population Commission, NPC, 2006). About $80 \%$ of its population is involved in agriculture and produces sesame, soybeans, groundnut, sweet potato, millet, rice, maize, sugarcane, oil palm, etc.

The State is bounded by Nasarawa and Taraba States to the North, Republic of Cameroun to the East, Cross River, Enugu and Ebonyi States to the South and Kogi State to the West (Benue State Agricultural and Rural Development Authority, BNARDA, 2010). Benue State has a tropical Climate, which exhibit two distinct seasons. The rainy season last from April to October while the dry season last from November to March. The average rainfall varies from $1750 \mathrm{~mm}$ in the Southern part of the State to $1250 \mathrm{~mm}$ in the North. The hot season comes in mid March and April with temperatures ranging from $32^{\circ} \mathrm{C}$ to $38^{\circ} \mathrm{C}$ and high humidity. Benue State is made up of three agricultural zones; Northeast, Northwest and Southern agricultural zones. The State has a total land area of about 30,955 square kilometres.

\section{Sampling Technique}

In order to achieve the aims of this study, structuredquestionnaires were used to collect primary data from 205 groundnut farmers in the study area. Multistage sampling technique was adopted. The first stage involved the purposive selection of two Local Government Areas (LGAs) from the Northeast and the Southern agricultural zones each and one LGA from the Northwest agricultural zone based on their predominance in groundnut production. The second stage involved the random selection of three groundnut farming communities from each LGA. In stage three, 45 and 43 respondents were randomly selected from Kwande and Konshisha LGAs respectively in the Northeast zone; in the Southern zone, 30 respondents were randomly selected from Obi LGA and 35 from Oju LGA; and in the Northwest zone, 52 respondents were selected from Gwer East at random.

\section{Model/Variable Specification \\ Stochastic frontier production model}

The data for this study were fitted into CobbDouglas production forms of stochastic frontier production model and the best form was selected through the use of generalized log-like lihood test after meeting the econometric requirements. Cobb-Douglas production form is implicitly stated as:

$\operatorname{In} y_{i}=\beta_{0}+\sum \beta_{i} \operatorname{In}\left(X_{i}\right)+\left(V_{i}-\mu_{i}\right)-----(i)$

The explicit form is stated as follows:

$\operatorname{Ln} \mathrm{Y}=\mathrm{B}_{0}+\mathrm{B}_{1} \operatorname{Ln} \mathrm{X}_{1}+\mathrm{B}_{2} \operatorname{Ln} \mathrm{X}_{2}+\mathrm{B}_{3} \operatorname{Ln} \mathrm{X}_{3}+\mathrm{B}_{4} \operatorname{Ln} \mathrm{X}_{4}+$

$\mathrm{B}_{5} \operatorname{Ln} \mathrm{X}_{5}+\left(\mathrm{v}_{1}-\mathrm{u}_{1}\right)$. 
Where: $\Sigma=$ sign of summation, $\mathrm{Y}_{\mathrm{i}}=$ the output in Kilogram, $\mathrm{Bi}=$ parameters estimates, $\mathrm{X}_{1}=$ total land area under groundnut production in hectares, $\mathrm{X}_{2}=$ total labour used in mandays, $X_{3}=$ total quantity of fertilizer used in groundnut production in Kilogram, $\mathrm{X}_{4}=$ Total quantity of agrochemicals used in litres, $\mathrm{X}_{5}=$ total quantity of groundnut seeds used in kilogram, $\mathrm{V}_{\mathrm{i}}=$ random errors that are assumed to be independent and identically distributed as $\mathrm{N}\left(0, \sigma_{\mathrm{v}}^{2}\right)$ random variables and $\mu_{\mathrm{i}}=$ Non-negative technical inefficiency effects that are assumed to be independently distributed among themselves and between $V_{i}$ such that $\mu_{i}$ is defined by the truncation of the $N\left(\mu_{i}, \sigma\right)$ distribution.

\section{The technical inefficiency effects model:}

The technical inefficiency effect, $\mu_{\mathrm{i}}$ is defined as: $\mu \mathrm{i}=\delta_{0}+\delta_{1} I_{1}+\delta_{2} I_{2}+\delta_{3} I_{3}+\delta_{4} I_{4}+\delta_{5} I_{5}+\delta_{6} I_{6}+$ $\delta_{7} I_{7}$

$\mathrm{I}_{1}-\mathrm{I}_{7}=$ adaptation strategies adopted by groundnut farmers in the study area.

$\mu_{\mathrm{i}}=$ inefficiency effect, $\mathrm{I}_{1}=$ Improved/multiple varieties, $\mathrm{I}_{2}=$ Adjustment of/multiple planting dates, $\mathrm{I}_{3}=$ Alternative tillage practices, $\mathrm{I}_{4}=$ Off-farm employ ment, $\mathrm{I}_{5}$ $=$ Planting of trees, $\mathrm{I}_{6}=$ Contour terracing and $\mathrm{I}_{7}=$ Fertilizer application. 1 if an adaptation strategy was adopted, 0 if otherwise. $\delta_{0}$ and $\delta_{i}=$ coefficients (unknown parameters to be estimated along with the variance parameters $\delta^{2}$ and $\gamma$ ). The varience of the random errors, $\delta_{v}^{2}$ and that of the technical inefficiency effects $\delta_{\mu}^{2}$ and the overall variances of the model are related). The ratio $\gamma=$ $\delta_{u}^{2} / \delta_{v}^{2}$ measures the total variation of output from the frontier which can be attributed to technical inefficiency. The estimates of the parameters of the stochastic frontier production function and the inefficiency model will be obtained simultaneously (Coelli, 1996).The technical efficiency is defined in terms of the ratio of observed climate change challenges and inadequate access to credit might have negative influence on farmers adaptive capacity.

Table 1: Distribution of the Groundnut Farmers According to their Socioeconomic

Characteristics

\begin{tabular}{llll}
\hline Variables & Frequency & Percentage & Mean \\
\hline Age & & & 36.9 \\
$\leq 20$ & 6 & 2.9 & \\
$21-40$ & 135 & 65.9 \\
$41-60$ & 58 & 28.3 \\
$\geq 61$ & 6 & 2.9 \\
Sex & & \\
Female & 51 & 24.9 \\
Male & 154 & 75.1 \\
Marital Status & & & \\
Single & 49 & 23.9 \\
Married & 129 & 61.5 \\
\hline
\end{tabular}

output $\left(\mathrm{Y}_{\mathrm{i}}\right)$ to the corresponding frontier output $\left(\mathrm{Y}_{\mathrm{i}}\right)$ conditioned on the level of input used by the farmers (Battese \& coelli, 1995). Hence the technical efficiency $\left(\mathrm{TE}_{\mathrm{i}}\right)$ of the groundnut farmers will be expressed as: $\mathrm{TE}_{\mathrm{i}}=y_{i} / y_{i}^{*}=\mathrm{f}\left(\mathrm{X}_{\mathrm{i}}, \mathrm{B}\right) \exp \left(\mathrm{V}_{\mathrm{i}}-\mu_{\mathrm{i}}\right) / \mathrm{f}\left(\mathrm{X}_{\mathrm{i}} \beta\right) \exp \mathrm{V}=\exp \quad(-\mu \mathrm{i})$. Where $Y_{\mathrm{i}}=$ Observed output, $Y_{i}^{*}=$ Frontier output, $\mathrm{TE}_{\mathrm{i}}=$ 0 to 1

\section{RESULTS AND DISCUSSION} Socioeconomic Characteristics of the Respondents

Table 1 shows that majority $(65.9 \%)$ of the groundnut farmers fell within the ages of 21-40 years. The average age of the farmers was 36 years. This means that groundnut farmers in the study area were in the economically productive age and groundnut production will tend towards an increase. The study reveals that groundnut farming was dominated $(75.1 \%)$ by the male and this calls for increased participation of the female in groundnut production in the study area.The result reveals also that majority $(61.1 \%)$ of the farmers were married with an average household size of 6 persons and this implies that, the farmers were responsible and family labour might be available. This study reveals that $95.6 \%$ of the respondents had formal education with an average of 10.4 schooling years. This means that respondents in the study area attended secondary school or its equivalent. This finding agrees with result of Ogundari (2008) that cash crop farmers in Nigeria had an average age of schooling of 10 years.Majority $(54.6 \%, 82.9 \%$ and $74.1 \%$ did not belong to any social group,have access to extension services and credit respectively. The limited access to extension services might create a gap between the farmers and useful information that could help them cope with 


\begin{tabular}{llll}
\hline Divorced & 17 & 8.3 & \\
Widowed & 13 & 6.3 & 5.9 \\
Household Size & & & \\
$\leq 5$ & 102 & 49.8 & \\
$6-10$ & 88 & 42.9 & \\
$11-15$ & 13 & 6.3 & \\
$\geq 16$ & 2 & 1.0 & \\
Level of Education & & & \\
Non-formal & 9 & 4.4 & \\
Primary & 45 & 22.0 & \\
Secondary & 110 & 53.7 & \\
Tertiary & 41 & 20.0 & \\
Access to Extension Services & & 82.9 & \\
No & 170 & 17.1 & \\
Yes & 35 & 54.6 & \\
Social Participation & & 21.5 & \\
No & 112 & 18.0 \\
1 & 44 & 5.9 & \\
2 & 37 & 74.1 & \\
$\geq 3$ & 12 & 1.5 & \\
Access to Credit & & 24.4 \\
No Access & 152 & \\
Formal & 3 & \\
Informal & 50 & & \\
\hline
\end{tabular}

\section{Source: Field Survey, 2018}

Years of Climate Change Awareness and Perception of Groundnut Farmers in Benue State

Table 2 reveals that $61.5 \%$ of the farmers were aware of climate change for at most 5 years, $32.7 \%$ were aware of climate change for 6-15 years, $3.4 \%$ were aware of climate change for $16-25$ years and only $2.4 \%$ of the respondents were aware of climate change for at least 26 years. The study also shows that $62.0 \%$ of the respondents perceived that there was delayed and/or erratic rainfall during the period of climate change awareness, $56.1 \%$ perceived that there was high temperature, $45.4 \%$ perceived decreased rainfall, $49.3 \%$ of the farmers perceived increased incidence of pest and disease, $28.8 \%$, $28.8 \%, 38.5 \%, 37.6 \%$ and $37.1 \%$ respectively perceived that there was wind effect, nutrient leaching, increased soil erosion, increased solar radiation and flood. Only about $17.1 \%$ of the respondents perceived that there was carbon (IV) oxide effect.

\section{Table 2: Distribution of the Farmers by their Years of Climate Change Awareness and Perception}

\section{Variables}

Years of climate change awareness

$\leq 5$

6-15

$16-25$

$\geq 26$

Climate change perception

Delayed /erratic rainfall

High Temperature

Decreased Rainfall

Pest and Disease

Wind Effect

Frequency
Percentage

Mean

$\begin{array}{cl}126 & 61.5 \\ 67 & 32.7 \\ 7 & 3.4 \\ 5 & 2.4 \\ & \\ 127 * * & 62.0 \\ 115^{* *} & 56.1 \\ 93 * * & 45.4 \\ 101 * * & 49.3 \\ 59 * * & 28.8\end{array}$


Nutrients Leaching

Soil Erosion

Solar Radiation

Flood

Carbon (iv) oxide

$\begin{array}{cc}59 * * & 28.8 \\ 79 * * & 38.5 \\ 77 * * & 37.6 \\ 76 * * & 37.1 \\ 35 * * & 17.1\end{array}$

adopted planting of trees and $54.1 \%$ of the respondents were involved in off-farm employment as source of income to aid farming activities. Only about $13.2 \%$ of the farmers applied fertilizer on their groundnut farms as a climate change adaptation strategy and none of the farmers adopted irrigation and shading to cope with climate change. This means that the farmers' awareness of climate change informed their decision to adopt adaptation measures to reduce the adverse effect of climate change.

Table 3:Distribution of the Farmers by Climate Change Adaptation Strategies Adopted

\begin{tabular}{lll}
\hline Variables & Frequency & Percentage \\
\hline & & 53.2 \\
Improved/Multiple Varieties & $109^{* *}$ & 85.9 \\
Adjustment of/Multiple Planting Dates & $176^{* *}$ & 60.0 \\
Alternative Tillage Practices & $123^{* *}$ & 22.0 \\
Tree Planting & $45^{* *}$ & 86.3 \\
Contour Terracing & $177^{* *}$ & 54.1 \\
Off-farm Employment & $111^{* *}$ & 13.1 \\
Fertilizer Application & $27^{* *}$ & - \\
Irrigation & - & - \\
Shading & - & \\
\end{tabular}

Source: Field Survey, 2018

** Multiple Responses

\section{Technical Efficiency for Groundnut Farming in Benue State}

The result of technical efficiency is presented on table 4. The result of the Cobb-Douglas stochastic frontier model shows that there was variation in technical efficiency among the groundnut farmers in the study area. The technical efficiency varied between 0.24 (24.0\%) and $0.97(97.0 \%)$ with a mean of $0.90(90.0 \%)$. The result shows that majority $(75.0 \%)$ of the farmers had technical efficiency of at least $0.91(91 \%), 22.0 \%$ had technical efficiency within $0.61-0.90,1.5 \%$ and $0.5 \%$ of the farmers had technical efficiency within the range of 0.31 0.60 and at most 0.30 respectively. This result means that there is little opportunity for increased efficiency about 0.1 given the present state of production technology. This result is similar to the result of Taphee and Jongur (2014) who obtained a mean technical efficiency of 0.97 in their study on productivity and efficiency of groundnut farming in Taraba State, Nigeria.

Table 4: Distribution of Technical Efficiency for Groundnut Farmers in Benue State 


\begin{tabular}{|c|c|c|c|}
\hline Ffficiency Index & & Frequency & Percentage \\
\hline$\leq 0.30$ & & 1 & 0.5 \\
\hline $0.31-0.60$ & & 3 & 1.5 \\
\hline $0.61-0.90$ & & 47 & 22.9 \\
\hline$\leq 0.91$ & & 154 & 75.0 \\
\hline Total & & 205 & 100.0 \\
\hline Minimum Efficiency & 0.24 & & \\
\hline Maximum Efficiency & 0.97 & & \\
\hline Mean Efficiency & 0.90 & & \\
\hline
\end{tabular}

\section{Source: Field Survey, 2018}

The Effects of Climate Change Adaptation Strategies on Technical Efficiency of Groundnut Production in Benue State

The Cobb-Douglas stochastic frontier model with inefficiency effects was selected as the preferred model that best fit the data for the groundnut farmers. The Maximum Likelihood Estimates for the parameters are presented in table 5. Farm size was highly significant at $1 \%$ level of probability. The estimated value for the gamma (0.2689) and sigma square (0.2376) were all significant at $1 \%$ level of probability and this indicates that the technical inefficiency is highly significant for groundnut production activities. The gamma parameter shows the relative magnitude of the variation in output associated with technical inefficiency. The derived coefficients from the Maximum Likelihood Estimates represent the percentage change in the explained variable as a result of the percentage change in the explanatory variables.The inefficiency parameters establish that adjustment of/multiple planting dates and alternative tillage practices decreased inefficiency. Improved/multiple varieties, off-farm employment and planting of trees increased inefficiency of groundnut production in the study area.

Table 5: Maximum Likelihood Estimates (MLE) of the Stochastic Frontier production Function for Groundnut Farmers in Benue State

\begin{tabular}{llc}
\hline Variables & Coefficients & t-ratio \\
\hline & & \\
Production model & Beta & $10.6460^{* * *}$ \\
Constant & 7.0407 & $6.6280^{* * *}$ \\
Farm Size & 0.9030 & 0.1813 \\
Seed & 0.0222 & -0.7767 \\
Fertilizer & -0.0089 & 0.3644 \\
Herbicide & 0.0052 & 0.7720 \\
Labour & 0.0375 & -1.1563 \\
Inefficiency model & Delta & $2.4866^{* *}$ \\
Constant & -0.4673 & $-2.7528^{* * *}$ \\
Improved/multiple Varieties & 0.8728 & $-2.7203^{* * *}$ \\
Adjustment of/Multiple Planting Dates & -0.7132 & $2.1556^{* *}$ \\
Alternative Tillage Practices & -0.6159 & -1.3379 \\
Planting of Trees & 0.5509 & $1.8391^{*}$ \\
Contour Terracing & -0.3037 & 1.0779 \\
Off-farm Employment & 0.4907 & $12.6788^{* * * *}$ \\
Fertilizer application & 0.0109 & $3.4587^{* * * *}$ \\
Diagnostic parameters & & \\
Sigma Squared & 0.2376 & \\
Gamma & 0.2689 & \\
Log Likelihood Function & -115.444 & \\
\hline & & \\
\hline
\end{tabular}




\section{Source: Field survey, 2018}

${ }^{*}, * *$ and ${ }^{* * *}$ represent $10 \%, 5 \%$ and $1 \%$ significant levels of probability respectively

\section{CONCLUSION}

The result of this study established that groundnut farmers in the study area are aware of climate change and this informs their decision to adopt measures to cope with the changing climate. The adopted measures had influence on the efficiency of groundnut production. In spite of the efforts put in place by the farmers to adapt to climate change, inadequate extension service delivery and lack of access to credit hindered the appropriate use of adaptation measures; based on these, the following recommendations are made.

i. There is need to emphasize adequate educationwith the help of extension agents to facilitate the farmers' adaptation to climate change.

ii. Government should make efforts to support credit facilities to help improve farmers' capacity to adapt to climate change.

\section{REFERENCES}

[1] Ashley, J. (1993). Drought and Crop Adaptation, in Dry land Farming in Africa, (Rowland, R.J. ed). Macmillan Education Limited, London and Basingstoke.

[2] Battese, G.E. \&Coelli, T.J. (1995). A model for technical inefficiency effect in stochastic frontier production functions for panel data. Empirical Economics, 20: 325335.

[3] Battisti, D.S. \& Nay lor R.L. (2009).Historical Warnings of Future Food Insecurity with Unprecedented Seasonal Heat. Science, 323: 240.

[4] Beghin, J., Diop N., Matthey, H., \&Sewadah, M. (2003). "The Impact of Groundnut Trade Liberalization: Implication for the Doha Round". Mimeo, Selected Paper presentation at the 2003 AAEA Annual Meetings, Montreel.

[5] Benue State Agricultural and Rural Development Authority (BNARDA) (2010). Annual report. BNARDA, Makurdi.

[6] Coelli, T.J. (1996). A Guide to frontier version 4.1: A computer programme for stochastic frontier production and cost function estimation (Working Paper). Armidale, Australia: University of New England, Center for Efficiency and Productivity Analysis. Department of Econometrics.

[7] Food and Agriculture Organization,FAO (2006). Production Year Book, vol. 60, Rome, Italy.

[8] Intergovernmental panel on climate change (IPCC) (2007). Climate Change: Synthesis Report. Cambridge. Cambridge University Press.
[9] Khanal, R.C. (2009). Climate Change and the Organic Agriculture. The Journal of Agriculture and Environment, 10:100-109, Review Paper.

[10] Kurukulasuriy a, P. \& Mendelsohn, R. (2006). A Ricardian Analysis of the Impact of Climate Change on African Crop Land. CEEPA Discussion paper No.8. Centre for Environmental Economics and Policy in Africa. University of Pretoria, Pretoria, South Africa.

[11] Maddison, D. (2006). The perception of and adaptation to climate change in Africa. CEEPA discussion paper No. 10, CEEPA, University of Pretoria, South Africa.

[12] Mark. W.R., Mandy, Y., Gary, B., Lann, H., Saleemul \& Rowens, V.S. (2008). Climate change and Agriculture. Threats and opportunities. Federal Ministry for Economic Cooperation and Development, Germany.

[13] Mendelsohn, R. (2000). Measuring the effect of climate change on developing country agriculture. Two essays on climate change and agriculture : A developing country perspective. FAO economic and social development paper 145.

[14] National Population Commission (NPC) (2006). 2006 Nigerian census figures. National Population Commission, Abuja.

[15] Nhemachena, C. \& Hassan, R. (2007).Micro-level analy sis of farmers' adaptation to climatechange in Southern Africa . (IFPRI Discussion paper No. 00714). Washington DC, USA: International Food Policy Research Institute (IFPRI), Environmental and Production Technology Division.

[16] Smit, B., Burton, I., Klein, R.J.T. \&Wandel, J. (2000).An anatomy of adaptation to climate change and variability. Climatic Change, 45: 223-251.

[17] Smit, B. \&Pilifosova, O. (2001). Adaptation to Climate Change in the Context of sustainable Development and equity, in climate change 2001: impacts, Adaptation and Vulnerability, chapter 18, Cambridge, Cambridge University Press.

[18] Taphee, G.B. \&Jongur, A.A.U. (2014). Productivity and efficiency of groundnut farming in Northern Taraba State, Nigeria. Journal of agriculture and sustainability,5 (1): 45-56. 